\title{
Molecular Characterization of Soybean Mosaic Virus NIa Protein and its Processing Event in Bacterial Expression
}

\author{
${ }^{1}$ Bong Kum Choi, ${ }^{1}$ Jae Sung Park, ${ }^{1}$ Hye Jin Ahn, ${ }^{1}$ Hye Jung Yum, ${ }^{1}$ Vasudevan Ayyappan \\ ${ }^{1}$ Lakshmi Sumitra Vijayachandran, ${ }^{1} \mathrm{Ji}$ Sue Kim, ${ }^{1}$ Sei Chang Kim and ${ }^{1,2}$ Chang Won Choi \\ ${ }^{1}$ Department of Biology and Medicinal Science, Pai Chai University, Daejeon, Korea 302-735 \\ ${ }^{2}$ Biomedicinal Research Center (RRC), Pai Chai University, Daejeon, Korea 302-735
}

\begin{abstract}
Soybean mosaic virus (SMV)-CN18 is an Rsv resistance-breaking (RB) isolate to overcome soybean resistance genes $R s v 1, R s v 3$ and $R s v 4$. The aim of this study was to characterize nuclear inclusion protein a (NIa protein) of RB isolate at the molecular level and demonstrate its processing into genome-linked protein (VPg) and NIa-Pro domains in Esherichia coli containing a bacterial expression $\mathrm{pET}$ vector inserted with NIa gene. The full-length of NIa gene was synthesized by reverse transcription-polymerase chain reaction (RT-PCR) and its 1298 nucleotides (nt) and 432 amino acids (aa) were deduced. The nt and aa sequences of NIa gene of SMV-CN18 shared high identities with the corresponding sequences of the NIa gene of the known SMV isolates, suggesting that the NIa is a highly conserved protein. The NIa-Pro domain contains a highly conserved structural motif for proteolysis, while the VPg domain contains a nuclear localization signal (NLS), a putative NTPbinding site and cellular factor-binding sites. The phylogenetic tree revealed that less divergence of NIa protein exists among twelve SMV isolates, which can be supported by a low bootstrap value between clades. In addition, the full-length of NIa gene, amplified by RT-PCR, was ligated into pET$28 \mathrm{~b}$ E. coli expression vector with an $\mathrm{N}$-terminal $\mathrm{His}_{6}$-tag. Optimal conditions for expression were at $1 \mathrm{mM}$ treatment of IPTG at $25^{\circ} \mathrm{C}$ for $5 \mathrm{hr}$. The released protein from bacterial lysates remained soluble and proved the processing form of the NIa polyprotein. E. coli expression system shows the processed product of $29 \mathrm{kDa}$ VPg in SDS-PAGE confirmed by western blot analysis in both crude extracts and purified elution products, using $\mathrm{Ni}^{2+}$-NTA resin. The present study indicates that the $\mathrm{N}$-terminal region of NIa which is processed and expressed in bacteria.
\end{abstract}

Key words: Soybean mosaic virus (SMV), Rsv resistance-breaking (RB) isolate, nuclear inclusion protein a (NIa), processing, genome-linked protein (VPg), NIa-Pro, highly conserved protein, E. coli expression

\section{INTRODUCTION}

Soybean mosaic virus (SMV), a member of the genus Potyvirus, is a major pathogen of soybean (Glycine $\max$ L.). SMV has a positive-sense singlestranded RNA genome of 9588 nucleotides, with VPg on the 5'end and poly(A) track at the 3'end. The genome of potyvirus encodes a single large polyprotein that is proteolytically processed by three virus-encoded protease $^{[1]}$. One of the proteases, nuclear inclusion protein a (NIa), possessed structural motifs that showed similarity with cellular serine protease, with the substitution of Ser by a Cys as the active site $e^{[2,3]}$. The NIa is actually a $49 \mathrm{kDa}$ polyprotein consisting of two domains, the genome-linked protein ( $\mathrm{VPg}$ ) domain at the $\mathrm{N}$-terminus and the protease (NIa-Pro) domain at the C-terminus ${ }^{[4,5]}$. The NIa protease plays an important role in the processing of the remaining two-thirds of polyprotein in cis-and trans-processing by catalyzing cleavage of at least six recognition sites ${ }^{[6-9]}$. The VPg is covalently linked to the 5'terminal base of a viral genome by a phosphodiester bond ${ }^{[10]}$, needed for virus replication $^{[11]}$. Its C-terminal region is important for the $\mathrm{VPg}-\mathrm{VPg}$ self-interaction and its central region is required for the HCpro and VPg interaction ${ }^{[12]}$. It may be involved in viral RNA synthesis by interacting with the viral RNA-dependent RNA polymerase $\mathrm{NIb}^{[13-16]}$, supporting that VPg is a putative primer for potyvirus replication as proposed for picornaviruses ${ }^{[17]}$. It has been considered as an analog of $\mathrm{m}^{7} \mathrm{G}$ cap of the mRNAs that might have a role in polyprotein translation because of the its interaction with capbinding translation initiation factor $\mathrm{eIF} \mathrm{E}^{[18,19]}$. In addition, it is implicated in viral movement from cell to cell $^{[20]}$ or vascular transport ${ }^{[21-23]}$. Its translocation from inoculated source leaves to the sink leaves, resulted in its accumulation in companion cells at an early stage of infection, suggesting that VPg may be a phloem protein to facilitate virus unloading ${ }^{[24]}$. 
Recently, we have reported twelve emerging Rsv resistance-breaking (RB) isolates of SMV, among them SMV-CN18 has an ability to overcome soybean resistance gene Rsv1, Rsv3 and Rsv4, respectively ${ }^{[25]}$. In this study, the NIa gene was synthesized by reverse transcription (RT)-PCR using SMV-CN18 genomic RNA as a template, compared its sequences of nucleotides (nt) and amino acids (aa) with those of eleven previous reported SMV isolates and characterized its expression in E. coli to observe the processing event into VPg and NIa-Pro domains.

\section{MATERIALS AND METHODS}

Viral strain, purification and RNA extraction: An RB isolate, SMV-CN18, was purified from the infected soybean leaves and its genomic RNA was prepared as described in a previous investigation $^{[25]}$.

RT-PCR amplification of NIa gene and cDNA cloning: The primers used for the amplification of NIa gene were designed based on the conserved nucleotide sequences of known SMV isolates and listed in Table 1. Reverse transcription (RT) reaction was performed on $100 \mathrm{ng}$ of viral RNA in a reaction volume of $20 \mu \mathrm{l}$ containing $50 \mathrm{mM}$ Tris- $\mathrm{HCl}, \mathrm{pH} 8.3,75 \mathrm{mM} \mathrm{KCl}, 10$ $\mathrm{mM}$ DTT, $3 \mathrm{mM} \mathrm{MgCl} 2,1 \mathrm{mM}$ dNTP, 50 pmol of reverse primer, $20 \mathrm{U}$ of RNase inhibitor (Takara, Japan) and $200 \mathrm{U}$ Molony murine leukaemia virus reverse transcriptase (Promega, USA). For amplification, $20 \mu \mathrm{l}$ of RT mix was added to $80 \mu \mathrm{l}$ of reaction mixture containing $10 \mathrm{mM}$ Tris- $\mathrm{HCl}, \mathrm{pH} 8.3,50 \mathrm{mM} \mathrm{KCl}$, $1.5 \sim 4.5 \mathrm{mM} \mathrm{MgCl}_{2}, 2.5 \mathrm{U}$ Taq polymerase (Takara, Japan), $0.25 \mathrm{mM}$ dNTP, $50 \mathrm{pmol}$ of forward and reverse primers each. The thermocycler (Bio-Rad, Gene Cycler, USA) was programmed for template denaturation at $94^{\circ} \mathrm{C}$ for $1 \mathrm{~min}$, primer annealing at $55^{\circ} \mathrm{C}$ for $2 \mathrm{~min}$ and DNA synthesis at $72^{\circ} \mathrm{C}$ for $3 \mathrm{~min}$. A final $7 \mathrm{~min}$ extension step at $72^{\circ} \mathrm{C}$ was performed at the end of 35 cycles. Ten RB isolates of SMV in a previous study ${ }^{[25]}$ were also subjected to monitor optimal condition for RT-PCR. The purified fragments were directly ligated into pGEM-T Easy Vector System (Promega, USA) and transformed into E. coli JM109 by conventional $\mathrm{CaCl}_{2}$ procedure. Transformants were selected on LuriaBertani (LB) medium supplemented with $100 \mu \mathrm{g} \mathrm{mL}^{-1}$ ampicillin, X-Gal and IPTG, incubating overnight at $37^{\circ} \mathrm{C}$.

Table 1: $\quad$ RT-PCR primers used for the cloning of Soybean mosaic virus NIa gene

\begin{tabular}{|c|c|c|}
\hline Gene & & Primer polarity Sequence $\left(5, \quad 3{ }^{\prime}\right)$ \\
\hline NIa-reverse & 3' end & TCCTTTCTCССТTGAACTGTC $^{\mathrm{a}}$ \\
\hline NIa-forward & 5' end & ATCAACTCAATGAAAGAAGAG \\
\hline
\end{tabular}

Nucleotide and amino acid sequences analyses and phylogenetic tree: The plasmid containing NIa gene was prepared from the transformed bacterial cells using QIA Plasmid Prep Kit (QIAGEN, Germany) and used for sequencing analysis. After linearization of the plasmid containing entire NIa coding region, nt sequences were determined in both directions by the dideoxynucleotide chain termination method using the ABI Model 337 automatic DNA sequencer. The complete genomic sequences of the SMV-CN18 were deposited as EMBL Database Accession no. AJ619757. For sequence comparisons, NIa gene products of the reference isolates were obtained from the NCBI data library including SMV-G2 (S42280) and -G7-1 (AF241739; then designated G7 in USA) ${ }^{[26]}$, SMV-G7d $(\text { AY216987) })^{[27]}$ SMV-N (NC002634) $)^{[28]}$, SMV-G5b (AY294044: then designated G5 in Korea) and -G7H (AY294045) ${ }^{[29]}$, SMV-HH5 (AJ310200: then designated Huanghuai) and -HZ (AJ312439: then designated Severe) ${ }^{[30]}$, as well as web-published isolates SMV-G72 (AY216010), -Aa (AB100442) and -Aa15-M2 (AB100443). Distance matrices for complete NIa sequences were calculated from the multiple sequence alignments by the DNAMAN version 5.2.9 (Lynnon Biosoft, Quebec, Canada). Phylogenetic analysis was performed using the generated matrices as an input in DNAMAN to build an unrooted tree and the statistical significance of branching was estimated by bootstrap resampled data sets based on 1000 replications.

Expression and purification of the His-tagged recombinant NIa protein: The pGEM-T Easy vector containing the amplified DNA fragments were digested with $N o t$ I, eluted by gel purification and re-ligated into NotI-digested expression vector pET-28b as $6 \mathrm{X}$ His fusion at N-terminus (Novagen, Germany). The goal of this strategy was to put the inserted gene under the control of the IPTG-inducible T7lac promoter. The final constructs were verified by sequencing. Then the recombinant plasmid (pSMV-NIa) was transformed into the expression host E. coli BL21(DE3). Expression of 6 $\mathrm{X}$ His-fused proteins was carried out according to manufacturer's protocol. A single colony was grown in Luria-Bertani (LB) medium containing kanamycin (30 $\mu \mathrm{g} \mathrm{mL}^{-1}$ ) to an $\mathrm{OD}_{600}$ of 0.6 , following isopropyl- $\beta$-D1-thiogalactopyrannoside (IPTG, final concentration of $0.01-5 \mathrm{mM}$ ) was added into the medium and incubated with shaking at $25^{\circ} \mathrm{C}$ or $37^{\circ} \mathrm{C}$ for $0 \sim 24 \mathrm{~h}$ to determine optimal condition. The protein was purified from E. coli cells $(100 \mathrm{~mL}$ culture) under the native or denaturing conditions ( $8 \mathrm{M}$ urea) using $\mathrm{Ni}^{2+}$-NTA resin (Qiagen, USA) as described in the manual 'QIAexpressionist' except that the non-denaturing lysis buffer contained 1 $\mathrm{mM}$ lysozyme and $1 \mathrm{mM}$ PMSF. In all cases, suspensions were sonicated three times $(30 \mathrm{~s}$ each with $1 \mathrm{~min}$ interval) prior to stirring at room temperature. 
Total proteins were analyzed by $10 \%$ SDS-PAGE followed by Western blotting to detect $6 \mathrm{X}$ His-tagged protein using $\mathrm{Ni}^{2+}$-NTA conjugated antibody against $6 \mathrm{X}$ His (Qiagen, USA). The membrane was developed by conventional method with nitroblue tetrazolium (NBT)/ 5-bromo-4-chloro-3-indolylphosphate (BCIP) (MBI Fermentas, Canada) in $100 \mathrm{mM}$ Tris, $100 \mathrm{mM} \mathrm{NaCl}$ and $5 \mathrm{mM} \mathrm{MgCl}_{2}$, $\mathrm{pH} 9.5$.

\section{RESULTS AND DISCUSSION}

RT-PCR amplification of NIa gene: Successful amplification of NIa gene from SMV-CN18 was performed by using forward and reverse primers in a range (1.5-4.5 $\mathrm{mM})$ of magnesium concentrations, among which $2.5 \mathrm{mM}$ of $\mathrm{MgCl}_{2}$ was the optimal condition (Fig. 1a). Under the optimal RT-PCR condition, we detected an array of amplification products of expected size 1,298 bp fragments of NIa gene that encoded 433 aa with a predicted molecular mass of $49 \mathrm{kDa}$ from soybean leaves inoculated with ten SMV RB isolates (Fig. 1b).

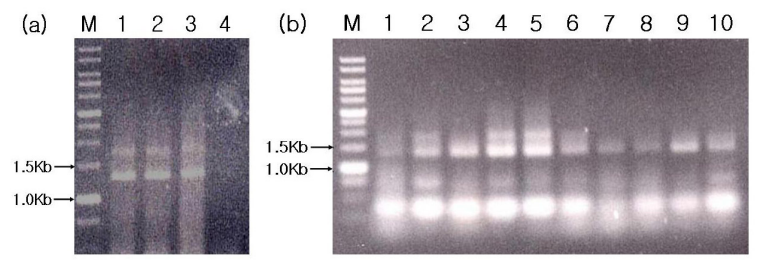

Fig. 1: (a) Amplified products of SMV-CN18 NIa gene by RT-PCR under various $\mathrm{MgCl}_{2}$ concentration. Lanes 1 (1.5 mM), 2 (2.5 mM), $3(3.5 \mathrm{mM})$ and $4(4.5 \mathrm{mM})$. (b) Amplified products of NIa gene of SMV isolates at 2.5 $\mathrm{mM} \mathrm{MgCl}_{2}$ by RT-PCR. Lanes 1 (CN1), 2 (CN2), 3 (CN3), 4 (CN9), 5 (CN12), 6 (CN13), 7 (CN15), 8 (CN17), 9 (CN21) and 10 (CN31). $\mathrm{M}$ represents $1 \mathrm{~kb}$ DNA ladder

NIa sequence comparisons and phylogenetic analysis: For the investigation of sequence diversity of NIa, the nt and aa sequences of SMV-CN18 were aligned with the corresponding sequences of the NIa gene of the known SMV isolates (data not shown). The highest nt sequence identity was $98 \%$ with SMV-HH5, while the lowest nt sequence identity was $92 \%$ with that of SMV-N. In aa similarities SMV-CN18 shows the value of $98 \%$ with G2 and G5b, respectively and $99 \%$ with the remaining nine isolates, suggesting that the NIa is a highly conserved protein among the isolates (Table 2). In addition, it possessed structural motifs for proteolysis that conserved among potyviruses ${ }^{[8,31]}$. Presumed codons among SMV isolates for the catalytic triad are composed of $\mathrm{H}_{32}, \mathrm{D}_{78}$ and $\mathrm{C}_{150}$. On the other hand, the VPg contains a nuclear localization signal (NLS) that is conserved among SMV isolates by the aa residues from 41 to 50 (KKGKGKGSTR). This NLS is quite similar to the NLS (KKGKTKGKTH) in Potato virus $A$ (PVA) $\mathrm{VPg}^{[24]}$ and the NLS (NKGKRKGTTR) in Tobacco etch virus (TEV) $\mathrm{VPg}^{[32]}$. SMV VPg also contains a conserved 7 aa residues $\left(\mathrm{A}_{38} \mathrm{YTKKGK}_{44}\right)$ which has been proposed as a putative NTP-binding site in the VPg of PVA, its deletion reduced nucleotidebinding capacity and debilitated uridylylation reaction ${ }^{[33]}$. Recently, a cellular factor called 'PVIP' that interacts with VPg of potyviruses has been identified in some plants. Two domains controlled the interactions with PVIP, suggesting that PVIP plays a role in assistant factor to support potyvirus movement in plants $^{[34]}$. Sequence comparison of SMV and other four potyviruses, Turnip mosaic virus (TuMV), Lettuce mosaic virus (LMV), PVA and TEV, were aligned for the two domains. It shows that four residues in the first domain (VP aa 1 to 16) and six residues in the second domain (VP aa 40 to 64) are identical with those of all four viruses (Fig. 2).

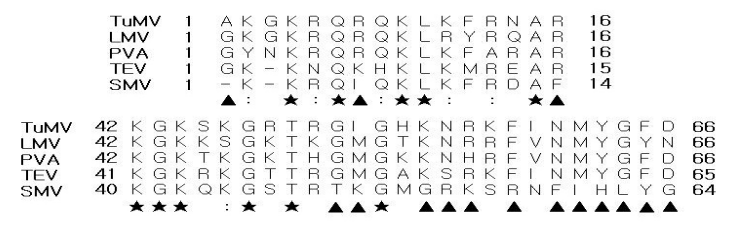

Fig. 2: Amino acid sequences of the determinant between VPg and PVIP interaction. SMV VPg sequences were aligned using DNAMAN version 5.2.9 software, with corresponding region from other potyviruses obtained from the NCBI data library. Only regions 1 to 16 and 40 (41 or 42) to 64 (65 or 66) are shown. Identical (star), related (:) and unmatched (triangle) amino acid sequences are indicated

Table 2: Sequence identities in nucleotides and amino acids of NIa gene between CN18 and known isolates of Soybean mosaic virus

\begin{tabular}{lll}
\hline Strain/ isolate & CN18 & Accession number \\
\hline G2 & $93 / 98^{\mathrm{a}}$ & S42280 \\
G5b & $93 / 98$ & AY294044 \\
G7-1 & $96 / 99$ & AF241739 \\
G7-2 & $97 / 99$ & AY216010 \\
G7d & $97 / 99$ & AY216987 \\
G7H & $96 / 99$ & AY294045 \\
Aa & $96 / 99$ & AB100442 \\
Aa15-M2 & $96 / 99$ & AB100443 \\
HH5 & $98 / 99$ & AJ310200 \\
HZ & $97 / 99$ & AJ312439 \\
N & $92 / 99$ & NC002634 \\
\hline
\end{tabular}

${ }^{a}$ Numbers in bold type at right corner refer amino acid sequence identities and numbers in plain type at left corner refer to nucleotide sequence identities.

DNAMAN version 5.2.9 was used in this study to determine the phylogenetic relationships among the NIa proteins of twelve SMV isolates (Fig. 3). In the previous study, the phylogenetic tree revealed that considerable divergence exists among P1 protein of 
twenty-five SMV isolates, all those SMV isolates can be grouped into three major types and seven subtypes by similarity clustering ${ }^{[25]}$. On the other hand, the less divergence of NIa protein existing among twelve SMV isolates, which can be supported by low bootstrap values between clades, suggests that the phylogenetic tree is essentially meaningless. Based on the result, it is logical to hypothesize that the recombination event in the NIa coding region rarely occurred between SMV isolates.

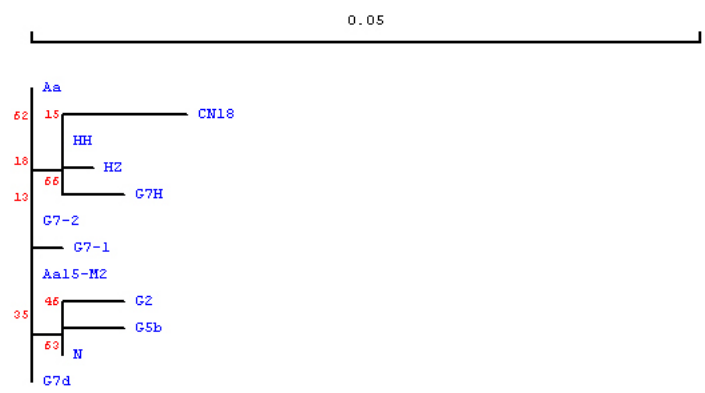

Fig. 3: Phylogenetic analysis for NIa protein amino acid sequences of $12 \mathrm{SMV}$ isolates. The tree (unrooted) was constructed by the DNAMAN version 5.2.9. The grouping occurred after bootstrapping the data (only values $>10 \%$ are shown) and the numbers on the branches indicate bootstrap percentages based on 1000 resamplings

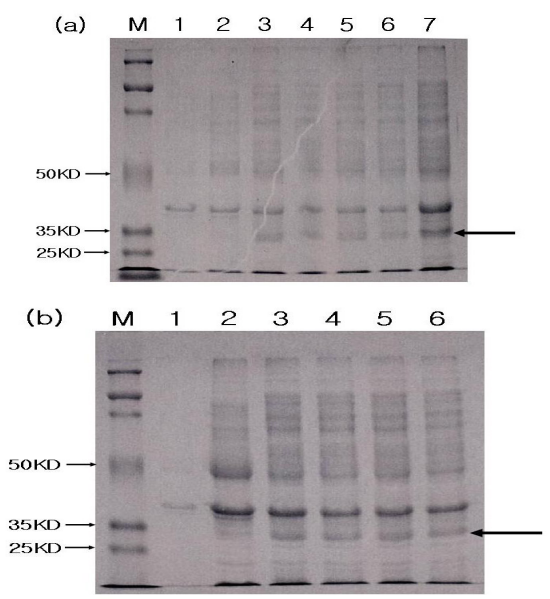

Fig. 4: $10 \%$ SDS-PAGE of the expressed NIa protein under various concentrations of IPTG at $37^{\circ} \mathrm{C}$ for $5 \mathrm{~h}$. (a) the supernatant of culture lysate after IPTG treatment, Lanes 1 (wild-type control, $1 \mathrm{mM}$ IPTG treatment), 2 (sample without IPTG treatment) and 3-7 (samples with $0.01 \mathrm{mM}, 0.05 \mathrm{mM}, 0.1 \mathrm{mM}, 0.5 \mathrm{mM}$ and $1 \mathrm{mM}$ IPTG treatment, respectively). (b) Lane 1 represents a wild-type control treated with 1 mM IPTG. Lanes 2-6 are samples treated with $1 \mathrm{mM}, 2 \mathrm{mM}, 3 \mathrm{mM}, 4 \mathrm{mM}$ and $5 \mathrm{mM}$ IPTG, respectively. $\mathrm{M}$ represents protein $\mathrm{Mr}$ marker and unlabelled arrow indicates the $\mathrm{VPg}$
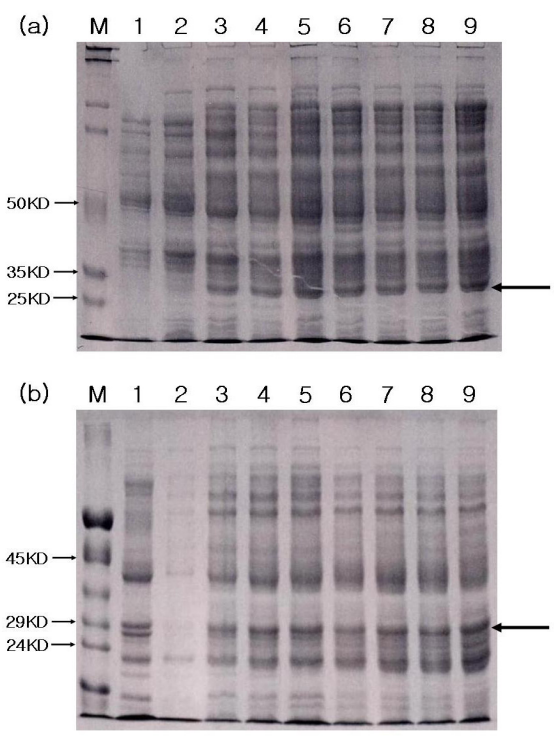

Fig. 5: Time course of NIa protein expression under 1 $\mathrm{mM}$ IPTG treatment at $25^{\circ} \mathrm{C}$. (a) Culture supernatants and (b) pellets. Lanes 1 (wild type control, culture for $5 \mathrm{~h}$ ) and 2 (no IPTG treated control, culture for $5 \mathrm{~h}$ ). Lanes 3-9 represent samples treated with IPTG for $1 \mathrm{~h}, 3$ h, $5 \mathrm{~h}, 7 \mathrm{~h}, 9 \mathrm{~h}, 12 \mathrm{~h}$ and $24 \mathrm{~h}$, respectively. $\mathrm{M}$ represents protein $\mathrm{Mr}$ marker and unlabelled arrow indicates the $\mathrm{VPg}$

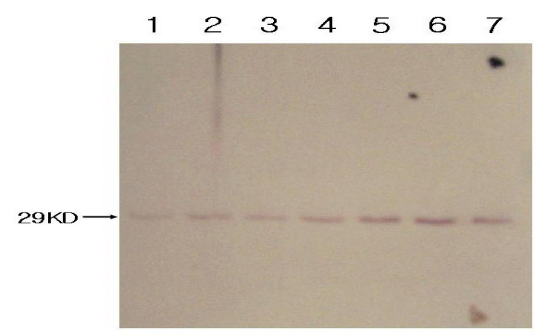

Fig. 6: Western blot analysis of the processed NIa protein. The recombinant VPg was detected about size of $29 \mathrm{KDa}$ protein using $\mathrm{Ni}^{2+}$-NTA conjugated antibody against $6 \mathrm{X}$ His. Lane 1 is crude extract, and lanes 2-7 represent the eluted protein samples during purification using $\mathrm{Ni}^{2+}$-NTA resin

Expression and purification of the His-tagged recombinant NIa protein: The protein was accumulated in high levels at $37^{\circ} \mathrm{C}$ under $1 \mathrm{mM}$ IPTG induction for $5 \mathrm{~h}$ but formed inclusion bodies in the bacterial cells (Fig. 4a, b). Optimal condition to express NIa protein as a soluble form in $E$. coli culture was observed under $1 \mathrm{mM}$ IPTG induction for $5 \mathrm{~h}$ at $25^{\circ} \mathrm{C}$ (Fig. 5a, b). At this temperature, the NIa protein was not only found in the pellets (Fig. 5a) but also in the supernatants of lysates (Fig. 5b). We designed the fusion of six His at the N-terminus of the protein when the coding region of NIa protein was subcloned into pET-28b. Therefore, the VPg with His-tag and NIa-Pro 
without His-tag could be released from the processed NIa, and only VPg could be detected by antibody specific to His-tag. Theoretically, the size of native NIa, NIa-Pro and VPg are 49, 27 and $23 \mathrm{kDa}$, respectively, from the cDNA sequences. Taking into account the Nterminal His-tag, the size of NIa, NIa-Pro and VPg were estimated as 55, 27 and $29 \mathrm{kDa}$, respectively. The position of band close to the expected size of protein was found at $29 \mathrm{kDa}$ on SDS-PAGE gel (Fig. 5a, b, lanes 3-9), and its migration was corresponding with the predicted VPg. The recombinant protein containing His residues is easily purified by metal-chelation chromatography ${ }^{[35]}$. To confirm the processing in the purified proteins from $E$. coli, we performed Western blotting using an $\mathrm{Ni}^{2+}$-NTA conjugated antibody against $6 \mathrm{X}$ His. We did not find the unprocessed polyprotein to bind $\mathrm{Ni}^{2+}$ affinity column, but detected the $29 \mathrm{kDa}$ protein corresponding to VPg (Fig. 6). Our results indicate that the anti-His antibodies recognized VPg but failed to recognize unprocessed polyprotein which further processed VPg and NIa-Pro. Our results were corresponding to the previous results that the VPg alone without NIa-Pro was detected when the entire coding region of NIa protein of TuMV was expressed in $E$. coli $^{[36]}$. The NIa-Pro of TEV was also expressed in $E$. coli as a recombinant protein with His-tag, but the expression of unprocessed polyprotein was unsuccessful $^{[37]}$. The full-length of TuMV NIa gene was expressed as an unprocessed polyprotein $(49 \mathrm{kDa})$ in $E$. coli by site-directed mutagenesis to block the processing as previously described by Ménard et al. ${ }^{[38]}$. According to our results and previous reports above mentioned, the unprocessed NIa polyprotein seems to exist for a brief time during its expression in E. coli.

\section{ACKNOWLEDGEMENTS}

This work was supported by a grant from Ministry of Commerce, Industry and Energy (MOICE) through the Research Center for Bio-Medicinal Resources (Bio-Med RRC) at Pai Chai University.

\section{REFERENCES}

1. Dougherty, W.G. and B.L. Semler, 1993. Expression of virus-encoded proteinases: Functional and structural similarities with cellular enzymes. Microbiol. Rev., 57: 781-822.

2. Gorbalenya, A.E., A.P. Donchenko, E.V. Koonin and V.M. Blinov, 1989. Cysteine proteases of positive strand RNA viruses and chymotrypsin-like serine proteases: A distinct super-family with a common structural fold. FEBS Lett., 243: 103-114.

3. Bazan, J.F. and R.J. Fletterick, 1990. Structural and catalytic models of trypsin-like viral proteases. Semin. Virol., 1: 311-322.
4. Murphy, J.F., R.E. Rhoads, A.G. Hunt and J.G. Shaw, 1990. The VPg of tobacco etch virus RNA is the $49-\mathrm{kDa}$ proteinase or the N-terminal $24-\mathrm{kDa}$ part of the proteinase. Virology, 178: 285-288.

5. Dougherty, W.G. and T.D. Parks, 1991. Posttranslational processing of the tobacco etch virus 49-kDa small nuclear inclusion polyprotein: identification of an internal cleavage site and delimitation of VPg and proteinase domains. Virology, 183: 449-456.

6. Carrington, J.C. and W.G. Dougherty, 1988a. Small nuclear inclusion protein encoded by a plant potyvirus genome is a protease. J. Virol., 61: 25402548.

7. Carrington, J.C. and W.G. Dougherty, 1988b. A viral cleavage site cassette: Identification of amino acid sequences required for tobacco etch virus polyprotein processing. Proc. Natl. Acad. Sci. USA., 85: 3391-3395.

8. Garcia, J.A., S. Lain, M.T. Cervera, J.L. Riechmann and M.T. Martin, 1990. Mutational analysis of plum pox potyvirus polyprotein processing by the NIa protease in Escherichia coli. J. Gen. Virol., 71: 2773-2779.

9. Joseph, J. and H.S. Savithri, 2000. Mutational analysis of the NIa protease from pepper vein banding potyvirus. Arch. Virol., 145: 2493-2502.

10. Wimmer, E., 1982. Genome-linked proteins of viruses. Cell, 28: 199-201.

11. Murphy, J.F., P.G. Klein, A.G. Hunt and J.G. Shaw, 1996. Replacement of the tyrosine residue that links a potyviral VPg to the viral RNA is lethal. Virology, 220: 535-538.

12. Yambao, M. LM., C. Masuta, K. Nakahara and I. Uyeda, 2003. The central and C-terminal domains of VPg of Clover yellow vein virus are important for VPg-HCPro and VPg-VPg interactions. J. Gen. Virol., 84: 2861-2869.

13. Hong, Y., K. Levay, J.F. Murphy, P.G. Klein, J.G. Shaw and A.G. Hunt, 1995. The potyvirus polymerase interacts with the viral coat protein and VPg in yeast cells. Virology, 214: 159-166.

14. Li, X.H., P. Valdez, R.E. Olvera and J.C. Carrington, 1997. Functions of the tobacco etch virus RNA polymerase (NIb): Subcellular transport and protein-protein interaction with $\mathrm{VPg} /$ proteinase (NIa). J. Virol., 71: 1598-1607.

15. Fellers, J., J. Wan, Y. Hong, G.B. Collins and A.G. Hunt, 1998. In vitro interactions between a portyvirus-encoded, genome-linked protein and RNA-dependent RNA polymerase. J. Gen. Virol., 79: 2043-2049.

16. Daros, J.A., M.C. Schaad and J.C. Carrington, 1999. Functional analysis of the interaction between VPg-proteinase (NIa) and polymerase (NIb) of tobacco etch potyvirus, using conditional and suppressor mutants. J. Virol., 73: 8732-8740. 
17. Wimmer, E., C.U. Hellen and X. Cao, 1993. Genetics of poliovirus. Annu. Rev. Genet., 27: 353436.

18. Wittmann, S., H. Chatek, M.G. Fortin and J.-F. Laliberté, 1997. Interaction of the viral protein genome linked of turnip mosaic potyvirus with the translational eukaryotic initiation factor (iso)4E of Arabidopsis thaliana using the yeast two-hybrid system. Virology, 234: 84-92.

19. Schaad, M.C., R.J. Anderberg and J.C. Carrington, 2000. Strain-specific interaction of the tobacco etch virus NIa protein with the translation initiation factor eIF4E in the yeast two-hybrid system. Virology, 273: 300-306.

20. Nicolas, O., S.W. Dunnington, L.F. Gotow, T.P. Pirone and G.M. Hellmann, 1997. Variations in the VPg protein allow a potyvirus to overcome $v a$ gene resistance in tobacco. Virology, 237: 452-459.

21. Schaad, M.C., A.D. Lellis and J.C. Carrington, 1997. VPg of tobacco etch potyvirus is a host genotype-specific determinant for long-distance movement. J. Virol., 71: 8624-8631.

22. Rajamäki, M.-L. and J.P.T. Valkonen, 1999. The $6 \mathrm{~K} 2$ protein and the $\mathrm{VPg}$ of potato virus $\mathrm{A}$ are determinants of systemic infection in Nicandra physaloides. Mol. Plant-Microbe Interact., 12: 1074-1081.

23. Rajamäki, M.-L. and J.P.T. Valkonen, 2002. Viral genome-linked protein ( VPg) controls accumulation and phloem-loading of a potyvirus in inoculated potato leaves. Mol. Plant-Microbe Interact., 15: 138-149.

24. Rajamäki, M.-L. and J.P.T. Valkonen, 2003. Localization of a potyvirus and the viral genomelinked protein in wild potato leaves at an early stage of systemic infection. Mol. Plant-Microbe Interact., 16: 25-34.

25. Choi, B.K., J.M. Koo, H.J. Ahn, H.J. Yum, C.W. Choi, K.H. Ryu, P. Chen and S.A. Tolin, 2005. Emergence of $R s v$-resistance breaking Soybean mosaic virus isolates from Korean soybean cultivars. Virus res., 112: 42-51.

26. Jayaram, C., J.H. Hill and W.A. Miller, 1992. Complete nucleotide sequences of two soybean mosaic virus strains differentiated by response of soybean containing the $R s v$ resistance gene. J. Gen. Virol., 73: 2067-2077.

27. Hajimorad, M.R., A.L. Eggenberger and J.H. Hill, 2003. Evolution of Soybean mosaic virus-G7 molecularly cloned genome in $R s v 1$ genotype soybean results in emergence of a mutant capable of evading Rsv1-mediated recognition. Virology, 314: 487-509.

28. Eggenberger, A.L., D.M. Stark and R.N. Beachy, 1989. The nucleotide sequence of a soybean mosaic virus coat protein-coding region and its expression in Escherichia coli, Agrobacterium tumefaciens and tobacco callus. J. Gen. Virol., 70: 1853-1860.
29. Lim, W.-S., Y.-H. Kim and K.-H. Kim, 2003. Complete genome sequences of the genomic RNA of soybean mosaic virus strains G7H and G5. Plant Pathol. J., 19: 171-176.

30. Chen, J., H.-Y. Zheng, L. Lin, M.J. Adams, J.F. Antoniw, M.-F. Zhao, Y.-F. Shang and J.-P. Chen, 2004. A virus related to Soybean mosaic virus from Pinellia ternate in China and its comparison with local soybean SMV isolates. Arch. Virol., 149: 349-363.

31. Dougherty, W.G., T.D. Parks, S.M. Cary, J.F. Bazan and R.J. Fletterick, 1989. Characterization of the catalytic residues of the tobacco etch virus $49-\mathrm{kDa}$ proteinase. Virology, 172: 302-310.

32. Schaad, M.C., R. Haldeman-Cahill, S. Cronin and J.C. Carrington, 1996. Analysis of the VPgproteinase (NIa) encoded by tobacco etch potyvirus: Effects of mutations on subcellular transport, proteolytic processing and genome amplification. J. Virol., 70: 7039-7048.

33. Puustinen, P. and K. Mäkinen, 2004. Uridylylation of the potyvirus $\mathrm{VPg}$ by viral replicase $\mathrm{NIb}$ correlates with the nucleotide binding capacity of VPg. J. Biol. Chem., 279: 38103-38110.

34. Dunoyer, P., C. Thomas, S. Harrison, F. Revers and A. Maule, 2004. A cysteine-rich plant protein potentiates Potyvirus movement through an interaction with the virus genome-linked $\mathrm{VPg}$. J. Virol., 78: 2301-2309.

35. Hochuli, E., H. Döbeli and A. Schacher, 1987. New metal chelate absorbents selective for proteins and peptide containing neighbouring histidine residues. J. Chromatog., 411: 177-184.

36. Laliberté, J.-F., O. Nicholas, H. Chatel, C. Lazure and R. Morosoli, 1992. Release of a 22-kDa protein derived from the amino-terminal domains of the 49-kDa NIa of turnip mosaic potyvirus in Escherichia coli. Virology, 190: 510-514.

37. Parks, T.D., E.D. Howard, T.J. Wolpert, D.J. Arp and W.G. Daugherty, 1995. Expression and purification of a recombinant tobacco etch virus NIa proteinase: Biochemical analysis of the fulllength and a naturally occurring truncated proteinase form. Virology, 210: 194-201.

38. Ménard, R. H. Chtel, R. Dupras, C. Plouffe and J.F. Laliberté, 1995. Purification of turnip mosaic potyvirus viral protein genome-linked proteinase expressed in Escherichia coli and development of a quantitative assay for proteolytic activity. Eur. J. Biochem., 229: 107-112. 